\title{
Palynological, Antioxidant and Physicochemical Properties of Pollen Loads from Eastern Anatolia
}

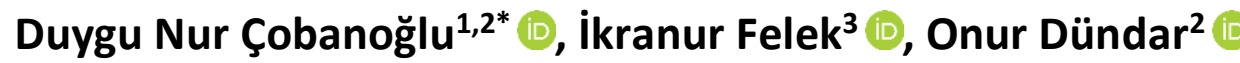 \\ ${ }^{1}$ Department of Crop and Animal Production, Vocational School of Food, Agriculture and Animal Sciences, Beekeeping \\ Program, Bingöl University, Bingöl, Turkey \\ ${ }^{2}$ Institute of Sciences, Bee and Bee Products Department, Bingöl University, Bingöl, Turkey \\ ${ }^{3}$ Faculty of Health Sciences, Nutrition and Dietetics Department, Bingöl University, Bingöl, Turkey
}

\section{Article History}

Received 26 November 2021

Accepted 08 December 2021

First Online 28 December 2021

\section{*Corresponding Author}

Tel.: +904262160012

E-mail: dncobanoglu@bingol.edu.tr

\section{Keywords}

Bee pollen

Eastern Anatolia

Palynological

$\mathrm{DPPH}$

TPC

\begin{abstract}
Bee pollen is a very important bee product with its wide biological content as well as being a protein source in the nutrition of larvae and young bees. In our study, palynological, antioxidant and some physicochemical analyses were performed on bee pollen loads taken from some provinces of the Eastern Anatolia Region of Turkey. According to the palynological analysis, pollen grains belonging to 62 plant taxa were observed. The highest and the lowest value of total phenolic content were determined as $15.05 \pm 0.46$ and $9.81 \pm 0.59 \mu \mathrm{g} \mathrm{GAE} / \mathrm{mg}$, respectively. Antioxidant analysis of DPPH radical scavenging activity was performed. As a result, the best activity was found at $16.93 \pm 0.92 \mu \mathrm{g} \mathrm{TE} / \mathrm{mg}$. The $\mathrm{pH}$, electrical conductivity and $\mathrm{L}$, $\mathrm{a}$ b values of the samples were found to be $4.62 \pm 0.015-4.86 \pm 0.005,2371.0 \pm 22.6-3008.0 \pm 22.9 \mathrm{mS} / \mathrm{cm}, 56.6 \pm 0.02-$ $59.9 \pm 0.01,11.5 \pm 0.01-12.2 \pm 0.02,50.9 \pm 0.01-53.1 \pm 0.03$, respectively. In this context, it can be said that the physicochemical and biological activities of bee pollen samples vary depending on the plant and geographical origin.
\end{abstract}

\section{Introduction}

Interest in the biological activity of foods is increasing day by day. Considering the polyphenol, vitamin and mineral content, the importance of the biological activities of bee products has been known from past to present (Bobiş et al., 2010). In addition, the value of them increased because of the viral pandemic that society faced after 2019. The immune-enhancing effect of bee products is emphasized (Lima et al., 2021).

Pollen load is one of the crucial bee products for young worker bees and larvae because of its high protein content and as a food supplement for human beings (LeBlanc et al., 2009). The honey bee (Apis mellifera L.) collects pollen from flowers' stamens of seed plants and combines this pollen with their oral secretions into pellets. Each pollen load has characteristic features such as color, size, morphology and aroma specific to the flower type (Yang et al., 2013). The botanical source and chemical composition of pollen load have a significant impact on its color. Bee pollen is named unifloral when it's derived from a single botanical source and its biochemical and organoleptic features are similar to those of the plant where it was collected. When bee pollen consists of several plants' pollen, it is called multifloral (Modro et al., 2009). Palynological analysis is the best method for determining the plants used by honey bees as pollen sources. The results of palynological evaluation also make it possible to determine the plant taxa that are used by bees as pollen forage in the regions (Atanassova \& Lazarova, 2010).

Bee pollen content varies depending on geographical origin, botanical source and beekeeping practices. In addition, storage conditions significantly affect this. Bee pollen contains carbohydrates, lipids, 
fatty acids, polyphenols, carotenoids, vitamins and minerals (Genc \& Dodologlu, 2002). Considering the chemical content, pollen loads are accepted as a complete food source in terms of nutrition. Pollen loads have a variety of activities, including antioxidants, antimicrobial, anti-inflammatory, and anticancer properties. Biological activities of pollen loads effects from phenolic compounds, flavonoids, vitamins and carotenoids (Kostić et al., 2020). Studies have found that bee pollen contains polyphenol groups such as quercetin, myricetin, rutin, tricetin, luteolin, selagin, isorhamnetin (Carpes et al., 2008; Freire et al., 2012 ).

In vivo studies the positive effects of pollen loads on health have increased. It was determined that they support the antioxidant system by increasing the levels of superoxide dismutase and glutathione in the blood and brain (Khalil \& El-sheikh, 2010). Considering the chemical content that changes depending on the geographical and floral source, it is important to determine the biochemical activities and physicochemical properties of bee pollen.

With oxygen respiration, molecules known as free radicals are formed in the body. Free radicals carry unpaired electrons in their outer orbitals. Therefore, they tend to bond easily. Antioxidants can prevent many possible damage in the body by reacting with free radicals. For example, antioxidants; It is effective in preventing oxidative stress, which is one of the leading causes of important diseases such as cancer, cardiovascular problems, diabetes, gastrointestinal diseases (Tsao \& Deng, 2004)

In this study, it was aimed to determine the palynological, antioxidant and some physicochemical properties of bee pollen samples taken from the provinces of Bitlis, Muş and Tunceli in the Eastern Anatolia Region of Turkey.

\section{Materials and Methods}

Bee pollen samples that were used in this study were obtained from the provinces of Bitlis, Muş and Tunceli from Eastern Anatolia Region of Turkey in 2021. Pollen loads were ground into powder before analysis. Bee pollen powders were stored at $-20^{\circ} \mathrm{C}$ before analysis.

\section{Palynological Analysis of Bee Pollen}

Palynological analysis of pollen loads was performed with minor revisions to the method proposed by Barth et al. (2010). $2 \mathrm{~g}$ pollen load was dissolved in $13 \mathrm{~mL} 70 \%$ ethanol solution. After resting the solution for 30 minutes to homogenize the pollen loads it was kept in the sonicator for 5 minutes. Pollen loads containing substantial oil, were subjected to ethanol extraction twice after centrifugation. The sediment was diluted in a 1: 1 water / glycerin mixture. A drop was taken from the well mixed pollen suspension and that was applied to the microscope slide by glycerin gelatin with basic fuchsin. Microscope slides were examined using a Leica DM 2500 brand microscope and pollen grains were determined by $60 \mathrm{x}$ and immersion objectives $(100 x)$. More than 500 pollen grains were counted on each slide in order to provide an evaluation of the relative abundance for every pollen type (number of pollen grains from species /total number of pollen grains). Pollen types were classified as predominant pollen (PP) ( $\geq 45 \%)$, secondary pollen (SP) (>16-44\%), important pollen (IP) (3-15\%), and minor pollen (MP) $(<3 \%)$ based on relative abundance (Barth et al., 2010).

\section{pH and Electrical Conductivity of Bee Pollen}

$2.5 \mathrm{~g}$ of bee pollen powder dissolved in $10 \mathrm{~mL}$ of distilled water. The solution was homogenized by mixing well and left it for 30 minutes. Then, $\mathrm{pH}$ and electrical conductivity values were recorded with a digital $\mathrm{pH}$ meter (Adaškevičiūtè et al., 2019).

\section{Color Analysis of Bee Pollen Samples}

Color analysis of bee pollen samples was carried out using the Minolta color measurement device. The powder form of pollen samples was placed in the device chamber and the results were recorded. Color results are given with $L, a, b$ values (Adaškevičiūtè et al., 2019).

\section{Extraction of Bee Pollen Samples}

Extraction of bee pollen samples was carried out for antioxidant and total phenolic analyses. $2 \mathrm{~g}$ of powdered pollen sample was weighed into falcon tubes and dissolved in $20 \mathrm{~mL}$ of $70 \%$ ethanol. The prepared solutions were incubated at $40^{\circ} \mathrm{C}$ for 1 hour in an ultrasound device. After 1 hour, the solutions were centrifuged at $3600 \mathrm{rpm}$ for 15 minutes. The supernatant was removed and passed through filter paper. Filtered extracts were stored at $-80^{\circ} \mathrm{C}$ until analysis (Almeida et al., 2017).

\section{Determination of Total Phenolic Content}

The total phenolic content of bee pollen samples was determined spectrophotometrically based on the Folin-Ciocalteu method. It was prepared using $0.2 \mathrm{~N}$ folin reagent and $7.5 \% \mathrm{Na}_{2} \mathrm{CO}_{3}$ distilled water. The solutions of bee pollen samples obtained as a result of extraction were diluted and $25 \mathrm{mg} / \mathrm{mL}$ concentration of pollen samples was used. Gallic acid was used to prepare the standard curve. Dilutions in the range of $7.8 \mu \mathrm{g} / \mathrm{mL}$ $500 \mu \mathrm{g} / \mathrm{mL}$ were prepared using $1 \mathrm{mg} / \mathrm{mL}$ gallic acid stock solution. After the solutions were pipetted into the falcon tubes, they were kept in the dark for 2 hours, and absorbance values were recorded at $760 \mathrm{~nm}$ wavelength. The procedure was repeated three times. The gallic acid equivalent of bee pollen samples was calculated using the gallic acid curve (Saroglu, 2018).

\section{DPPH Analysis}

DPPH radical scavenging assay was used to determine the antioxidant activity of bee pollen samples. A $0.1 \mathrm{mM}$ DPPH solution was prepared with ethyl alcohol. The dilution process was applied to the 
solution obtained by bee pollen extraction. Pollen solutions with a concentration of $5 \mathrm{mg} / \mathrm{mL}$ were used in the analysis by dilution. According to different trolox concentrations, standard curve was generated. The prepared solutions were kept in the dark for 45 minutes after pipetting. Finally, absorbance values were recorded with a spectrophotometer at a wavelength of $517 \mathrm{~nm}$. The procedure was carried out in 3 repetitions. Results are given as trolox equivalent (Freire et al., 2012).

\section{Statistical Analysis}

Each bee pollen sample was analysed in triplicate. Results are shown as arithmetic mean values \pm standard deviation. Statistical analyses were carried out using $R$ studio (R Core Team, 4.1 Version, 2020).

\section{Results and Discussion}

Palynological analysis was performed to determine the plant sources of pollen loads. As a result of the analysis bee pollen loads were classified into 4 groups according to the relative abundance (RA): predominant pollens (PP) ( $\geq 45 \%)$, secondary pollens (SP) (16-44\%), important pollens (IP) (>3-15\%) and minor pollens (MP) $(<3)$ (Table 1). If pollen grains $R A \geq 80 \%$, this indicates the botanical origin of bee pollen and it is named unifloral. In this study all pollen samples were accepted as heterofloral. In total, 64 pollen taxa distributed into 30 families were found in the pollen samples (Table 1).

Table 1. Pollen taxa identified from pollen loads and their RA

\begin{tabular}{|c|c|c|c|c|}
\hline & Muş & Tunceli & Bitlis 1 & Bitlis 2 \\
\hline \multicolumn{5}{|l|}{ Adoxaceae } \\
\hline Sambucus & 1.02 (MP) & 1.41 (MP) & & \\
\hline \multicolumn{5}{|l|}{ Asparagaceae } \\
\hline Muscari & & & 2.28 (MP) & 5.95 (IP) \\
\hline \multicolumn{5}{|l|}{ Amaryllidaceae } \\
\hline Allium & & & & $0.37(\mathrm{MP})$ \\
\hline Apiaceae & 1.27 (MP) & & & 1.12 (MP) \\
\hline Chaerophyllum & 3.81 (IP) & $0.20(\mathrm{MP})$ & & \\
\hline Daucus & & & 2.54 (MP) & \\
\hline Eryngium & & & 0.51 (MP) & \\
\hline Ferula & & $6.02(I P)$ & & $1.12(\mathrm{MP})$ \\
\hline Heracleum & & & $0.25(\mathrm{MP})$ & $0.37(\mathrm{MP})$ \\
\hline Pimpinella & 0.25 (MP) & & $0.25(\mathrm{MP})$ & \\
\hline \multicolumn{5}{|l|}{ Asteraceae } \\
\hline Achillea & & & & $1.86(\mathrm{MP})$ \\
\hline Anthemis & $0.25(\mathrm{MP})$ & & & \\
\hline Artemisia & & & & $0.37(\mathrm{MP})$ \\
\hline Centaurea & & & $0.76(\mathrm{MP})$ & \\
\hline Centaurea urvillei & & & $5.08(\mathrm{IP})$ & \\
\hline Cirsium & & & $0.25(\mathrm{MP})$ & \\
\hline Cyanus & $1.27(\mathrm{MP})$ & 9.04 (IP) & $0.76(\mathrm{MP})$ & \\
\hline Carthamus & 0.25 (MP) & & & \\
\hline Inula & $2.03(\mathrm{MP})$ & & $0.25(\mathrm{MP})$ & \\
\hline Silybum & & $0.20(\mathrm{MP})$ & & \\
\hline Taraxacum & & $0.20(\mathrm{MP})$ & $1.02(\mathrm{MP})$ & \\
\hline Brassicaceae & $7.61(\mathrm{IP})$ & 1.41 (MP) & & \\
\hline Brassica & & $21.29(\mathrm{SP})$ & & \\
\hline Isatis & $0.76(\mathrm{MP})$ & $2.41(\mathrm{MP})$ & & \\
\hline \multicolumn{5}{|l|}{ Boraginaceae } \\
\hline Echium & $0.25(\mathrm{MP})$ & $0.80(\mathrm{MP})$ & & \\
\hline \multicolumn{5}{|l|}{ Caryophyllaceae } \\
\hline Silene & & & & $0.74(\mathrm{MP})$ \\
\hline \multicolumn{5}{|l|}{ Cistaceae } \\
\hline Cistus & $12.69(\mathrm{IP})$ & $12.05(\mathrm{IP})$ & & \\
\hline Helianthemum & $5.08(\mathrm{IP})$ & & & \\
\hline
\end{tabular}


Bee Studies 13(2), 31-38

Table 1. Pollen taxa identified from pollen loads and their RA (continued)

\begin{tabular}{|c|c|c|c|c|}
\hline & Muş & Tunceli & Bitlis 1 & Bitlis 2 \\
\hline \multicolumn{5}{|l|}{ Convolvulaceae } \\
\hline Convolvulus & & & 0.51 (MP) & 1.12 (MP) \\
\hline \multicolumn{5}{|l|}{ Crassulaceae } \\
\hline Sedum & & $2.61(\mathrm{MP})$ & & \\
\hline Ericaceae & 0.25 (MP) & & & \\
\hline \multicolumn{5}{|l|}{ Fabaceae } \\
\hline Astragalus & 0.51 (MP) & 3.01 (IP) & & \\
\hline Lathyrus & 0.25 (MP) & 0.20 (MP) & & 0.37 (MP) \\
\hline Melilotus & & 1.00 (MP) & 0.76 (MP) & 7.43 (IP) \\
\hline Onobrychis & & $16.87(\mathrm{SP})$ & & \\
\hline Trifolium pratense & & & & 1.12 (MP) \\
\hline Trifolium & 2.79 (MP) & 0.20 (MP) & & \\
\hline \multicolumn{5}{|l|}{ Fagaceae } \\
\hline Quercus & $15.74(\mathrm{SP})$ & 0.60 (MP) & 3.81 (IP) & $5.95(\mathrm{IP})$ \\
\hline \multicolumn{5}{|l|}{ Fumariaceae } \\
\hline Fumaria & 1.02 (MP) & & & \\
\hline \multicolumn{5}{|l|}{ Hypericaceae } \\
\hline Hypericum & & & $9.14(\mathrm{IP})$ & 15.61 \\
\hline \multicolumn{5}{|l|}{ Juglandaceae } \\
\hline Juglans & & 0.20 (MP) & 2.03 (MP) & 1.86 (IP) \\
\hline Lamiaceae & 0.25 (MP) & 0.20 (MP) & & \\
\hline Lamium & $4.31(\mathrm{IP})$ & & & 0.37 (MP) \\
\hline \multicolumn{5}{|l|}{ Moraceae } \\
\hline Morus & 0.51 (MP) & & 1.02 (MP) & 0.74 (MP) \\
\hline \multicolumn{5}{|l|}{ Papaveraceae } \\
\hline Papaver & 22.59 (SP) & 2.21 (MP) & & 0.37 (MP) \\
\hline \multicolumn{5}{|l|}{ Plantaginaceae } \\
\hline Plantago & 0.76 (MP) & 0.20 (MP) & 0.51 (MP) & \\
\hline \multicolumn{5}{|l|}{ Polygonaceae } \\
\hline Rumex & 0.51 (MP) & 0.20 (MP) & & \\
\hline Poaceae & & 0.80 (MP) & 0.25 (MP) & \\
\hline Poa & 0.76 (MP) & & & \\
\hline \multicolumn{5}{|l|}{ Ranunculaceae } \\
\hline Nigella & & & & 0.37 (MP) \\
\hline Ranunculus & 2.28 (MP) & & & 0.37 (MP) \\
\hline \multicolumn{5}{|l|}{ Rhamnaceae } \\
\hline Paliurus spina christi & 0.76 (MP) & & & \\
\hline Rosaceae & 0.76 (MP) & $4.02(\mathrm{IP})$ & & $0.74(\mathrm{MP})$ \\
\hline Crataegus & 1.52 (MP) & & & \\
\hline Potentilla & 0.51 (MP) & & & \\
\hline Pyrus & & & $5.08(\mathrm{IP})$ & $3.72(\mathrm{IP})$ \\
\hline Rosa & & 0.20 (MP) & & \\
\hline Sanguisorba & 0.51 (MP) & 0.20 (MP) & 0.51 (MP) & \\
\hline \multicolumn{5}{|l|}{ Rutaceae } \\
\hline Citrus & 1.27 (MP) & & & \\
\hline \multicolumn{5}{|l|}{ Salicaceae } \\
\hline Salix & $3.30(\mathrm{IP})$ & 12.05 (IP) & $60.41(\mathrm{PP})$ & $47.96(\mathrm{PP})$ \\
\hline \multicolumn{5}{|l|}{ Scrophulariaceae } \\
\hline Verbascum & 2.28 (MP) & & & \\
\hline \multicolumn{5}{|l|}{ Xanthorrhoeaceae } \\
\hline Eremurus & & 0.20 (MP) & 2.03 (MP) & \\
\hline
\end{tabular}


In this study, the most common pollen grains from the plant families of Salicaeae (30.93\%), Fabaceae (8.63\%), Brassicaceae (8.37\%) and Cistaceae (7.45\%) were found in pollen samples, respectively. The results found are compatible with the literature (Bay et al., 2021). Taxa of Salix sp., Papaver sp., Cistus sp. appear with high incidence in bee pollen samples. The pollen diagram shows the percentage of pollen grains found for each taxa. According to the diagram, pollen loads was divided into two groups according to the similarity between the plant taxa determined as a result of the melissopalynological analysis. The first group consists of Bitlis 1 (1), Bitlis 2 (2) and the greatest similarity was found in this group. The second group Muş (3) and Tunceli (4) pollen loads, contained 15 common plant taxa.. Salix sp., Hypericum sp. and Quercus sp. plant taxa pollen grains were most common in Bitlis 1 and Bitlis 2 . Pollen grains of Cyanus sp., Brassica sp., Cistus sp., Onobrychis sp., Quercus sp., Papaver sp., Salix sp. plant taxa were found in Muş and Tunceli. Pollen grains belonging to the Cistus taxon were found in the pollen loads taken from Muş and Tunceli (Figure 1). This suggests that the beekeepers who produce these pollens can do wandering beekeeping. Because Cistus taxon does not belong to the Eastern Anatolian bee flora.

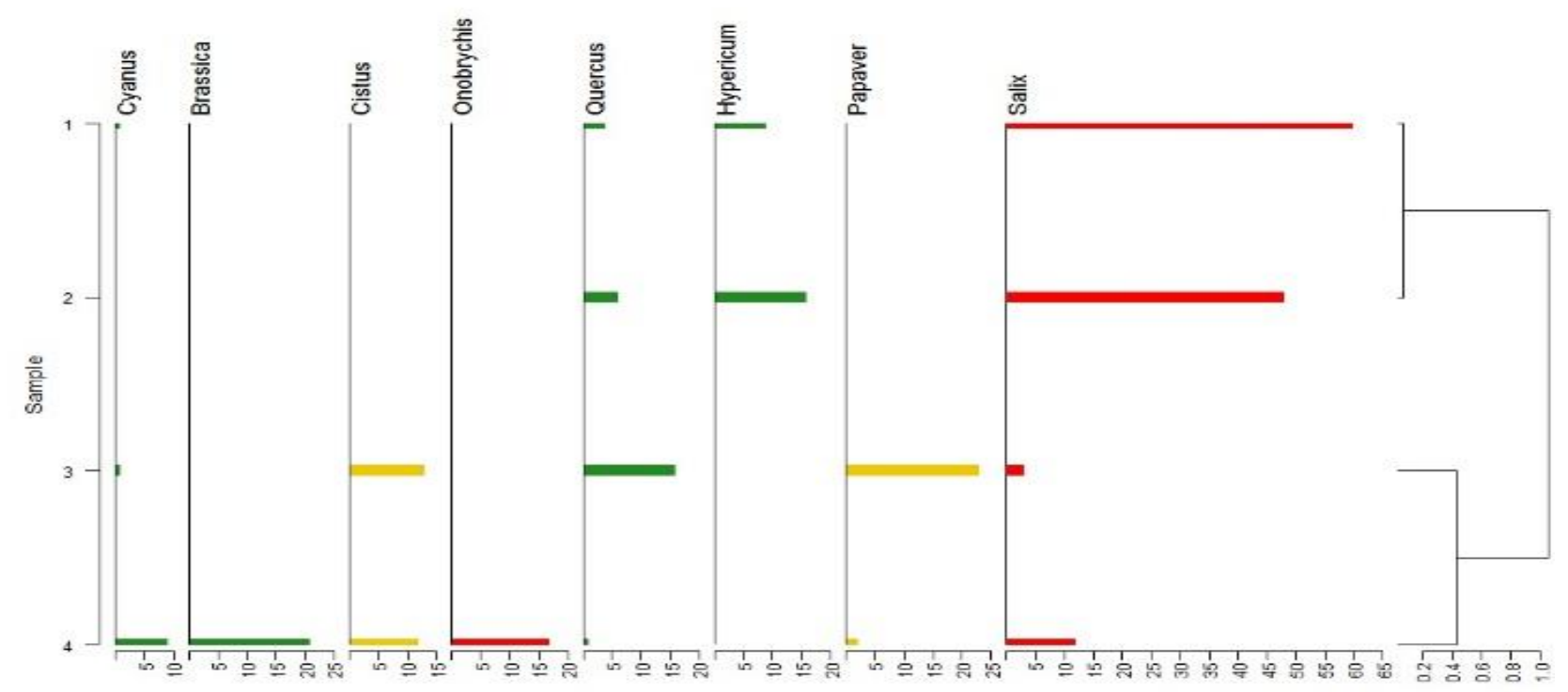

Figure 1. Pollen diagrams of pollen loads

According to PCA of melissopalynological analysis, there are two significant axes. The first principal component (PC1) explains $57.1 \%$ of the total variance, while the second component (PC2) explains $40.7 \%$. Fig. 2 shows that Onobrychis, Brassica, Cyanus, Cistus,
Papaver taxa constitute the positive part of PC1. All plant taxa except, Quercus, Papaver, Cistus constitute the positive part of PC2.

The $\mathrm{pH}$, electrical conductivity and color values of bee pollen samples are summarized in Table 2.

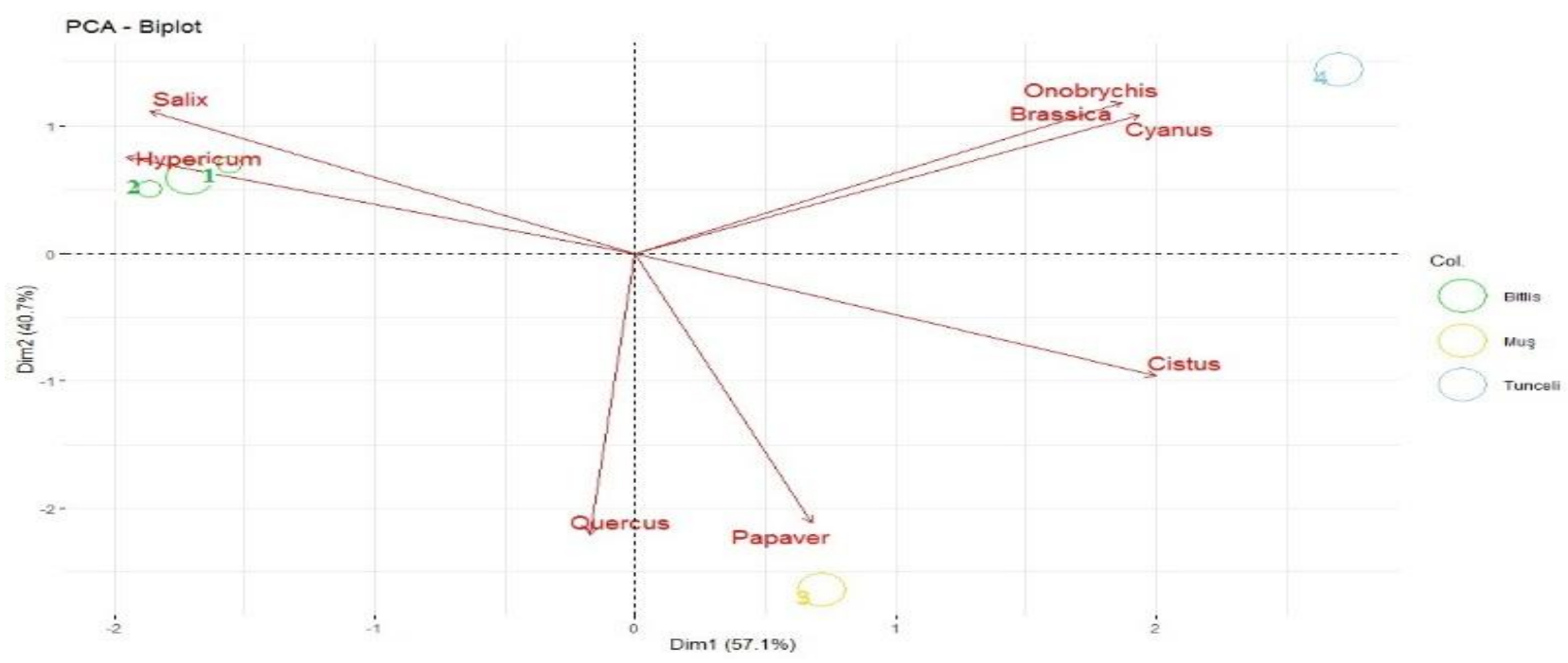

Figure 2. PCA biplot for melissopalynological analysis 
Table 2. Physicochemical parameters of bee pollen sample

\begin{tabular}{|c|c|c|c|c|c|}
\hline $\begin{array}{c}\text { Bee Pollen } \\
\text { Samples }\end{array}$ & pH & $\begin{array}{c}\text { Electrical } \\
\text { Conductivity } \\
\mathrm{ms} / \mathrm{cm}\end{array}$ & $\mathbf{L}^{*}$ & $a^{*}$ & $\mathbf{b}^{*}$ \\
\hline Bitlis 1 & $4.86 \pm 0.005$ & $2830.7 \pm 48.7$ & $58.3 \pm 0.02$ & $11.5 \pm 0.01$ & $51.6 \pm 0.01$ \\
\hline Bitlis 2 & $4.80 \pm 0.015$ & $2933.7 \pm 55.3$ & $57.4 \pm 0.01$ & $11.8 \pm 0.02$ & $51.3 \pm 0.03$ \\
\hline Mus & $4.62 \pm 0.015$ & $2371.0 \pm 22.6$ & $56.6 \pm 0.02$ & $12.2 \pm 0.02$ & $50.9 \pm 0.01$ \\
\hline Tunceli & $4.70 \pm 0.006$ & $3008.0 \pm 22.9$ & $59.9 \pm 0.01$ & $12.0 \pm 0.00$ & $53.1 \pm 0.03$ \\
\hline
\end{tabular}

The $\mathrm{pH}$ values of pollen samples varied between $4.62 \pm 0.015-4.86 \pm 0.005$. The lowest $\mathrm{pH}$ was observed in the pollen sample from the province of Muş, while the highest $\mathrm{pH}$ was observed in the pollen sample from the province of Bitlis. However, the $\mathrm{pH}$ values of the pollen samples were very close to each other and the pollen showed acidic properties. The highest electrical conductivity (EC) value was found to be $3008.0 \mathrm{~ms} / \mathrm{cm}$ in the Tunceli sample. The EC of the pollen samples was in the range of $2371.0-3008.0 \mathrm{mS} / \mathrm{cm}$ and the lowest EC was determined in the pollen sample of Muş province. $\mathrm{EC}$ value is a concept related to the presence of organic acids, proteins, sugars and minerals. The EC values of the analyzed pollen samples were found to be relatively high. This suggests that pollen samples may be a good source of organic acids and minerals. In the study investigating the physicochemical properties of bee pollen samples collected from countries such as Italy, Denmark, Poland, Spain, and Lithuania, $\mathrm{pH}$ values were found in the range of 4.3-5.2, similar to our study. The EC values were found to be $444-836 \mu \mathrm{S} / \mathrm{cm}$ and these values were found to be well below the pollen samples examined in our study (Adaškevičiūtè et al., 2019). In a study examining bee pollen samples from Portugal, $\mathrm{pH}$ values were close and found in the range of 4.5-5.1 (Feas et al., 2012). Color analysis of bee pollen samples using the Minolta color device. The results are given in Table 2 . in terms of $L^{*}, a^{*}, b^{*}$. The $L^{*}$ value was found to be between $56.6 \pm 0.02$ - 59.9 \pm 0.01 , the $a^{*}$ value was between $11.5 \pm 0.01-12.2 \pm 0.02$, and the $b *$ value was between $50.9 \pm 0.01-53.1 \pm 0.03$. The $L^{*}$ value is related to lightness-darkness, and it was found to be higher than 50 in all of the pollen samples examined, so it can be said that all of the samples are light colored. $A^{*}$ is red (+)green $(-)$, and $b^{*}$ is yellow (+)-blueness (-). It can be said that the color of the pollen samples is close to red according to the $a^{*}$ value, and the color of the samples is close to yellow according to the $b^{*}$ value. As a result, in general, pollen samples can be said to be red-yellow light colored. It is seen that the color values of the pollen samples belonging to the provinces examined are close to each other (Figure 3).

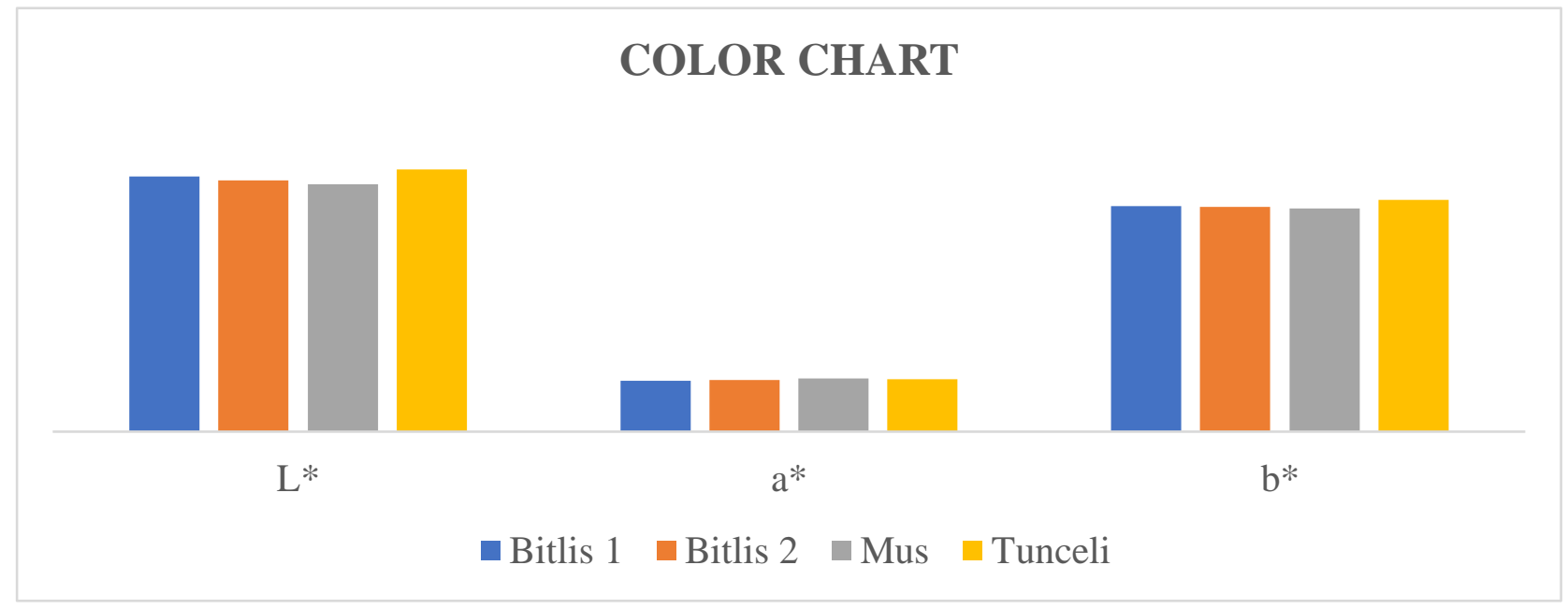

Figure 3. Color chart of bee pollen samples 
This situation can be associated with the fact that the pollen samples were obtained from nearby provinces and those provinces belonged to the same region. In a study examining the color values of 9 different pollen samples taken from the Eastern Black Sea Region Bayburt province, the $L^{*}$ value was determined in the range of 73.1-74.9. These values were higher than the pollen samples that were examined in our study. In addition, the $a^{*}$ value was determined in the range of 1.05-2.44, and the $b^{*}$ value was determined as 56.13-58.47. According to these values, it can be said that the samples have less redness and more yellowness than the pollen samples in our study (Saroglu, 2018). Thus, it can be thought that the color values of pollen samples may change depending on the changing regional differences.

Total phenolic contents (TPC) of bee pollen samples were determined as gallic acid equivalents and DPPH free radical scavenging activity was determined as trolox equivalents and is given in Table 3.

Table 3. TPC and DPPH activity of bee pollen samples

\begin{tabular}{lcc}
\hline Bee Pollen Samples & $\begin{array}{c}\text { Total Phenolic Content (TPC) } \\
\mu \mathrm{G} \mathrm{GAE} / \mathrm{mg} \text { bee pollen }\end{array}$ & $\begin{array}{c}\text { DPPH } \\
\mu \mathrm{g} \text { TE/ } \mathrm{mg} \text { bee pollen }\end{array}$ \\
\hline Bitlis 1 & $15.05 \pm 0.46$ & $15.94 \pm 0.15$ \\
Bitlis 2 & $14.41 \pm 0,59$ & $16.93 \pm 0.92$ \\
Muş & $9.81 \pm 0.59$ & $13.38 \pm 0,64$ \\
Tunceli & $11.57 \pm 0.48$ & $15.42 \pm 0.93$
\end{tabular}

The phenolic contents of the pollen samples were found to be between $9.81 \pm 0.59 \mu \mathrm{g} \mathrm{GAE} / \mathrm{mg}$ and $15.05 \pm 0.46 \mu \mathrm{g} \mathrm{GAE} / \mathrm{mg}$. Among the pollen samples, the lowest and the highest total phenolic content belonged to Muş and Bitlis 1 respectively. In a study examining the pollen samples obtained from Bayburt province, the highest total phenolic content was found to be $7.69 \mathrm{mg}$ $\mathrm{GAE} / \mathrm{g}$, and this value is lower than in our study (Saroglu, 2018). For $B$. napus subsp. napus $L$. pollen, the TPC value was found to be $1383.67 \mathrm{mg} \cdot \mathrm{kg}^{-}{ }^{1}$ (Fatrcová-Šramková et al., 2013). In another study examining the bee pollen from Portugal and Spain, TPC was detected in the range of 18.55-32.15 mg GAE/g (Pascoal et al., 2014). Considering the studies, it can be thought that the total phenolic content varies depending on the plant and geographical source of the bee pollen. In addition, within the scope of our study, it is seen that the phenolic content of pollen changes very little with regional proximity. The DPPH free radical scavenging activities of bee pollen samples were between $13.38 \pm 0.64$ and $16.93 \pm 0.92 \mu \mathrm{g} \mathrm{TE} / \mathrm{mg}$ bee pollen. While the Muş sample showed the lowest activity, the Bitlis 2 sample showed the highest activity. In parallel to the total phenolic content of the Muş sample, DPPH activity was also found to be low. In a study examining bee pollen from Portugal and Spain, DPPH activities were found in the range of $2.98-6.69 \mathrm{mg} / \mathrm{g}$ extract. It is seen that the DPPH activities of the pollen samples we used in our study were higher than in this study (Pascoal et al., 2014). According to the PCA of physicochemical analysis, there are two significant axes. The first principal component (PC1) explains $63.9 \%$ of the total variance, while the second component (PC2) explains $30.9 \%$. Fig.4 shows all parameters except $\mathrm{a}^{*}$ constitute the negative part of PC1. TPC, pH, DPPH constitute the positive parts of PC2.

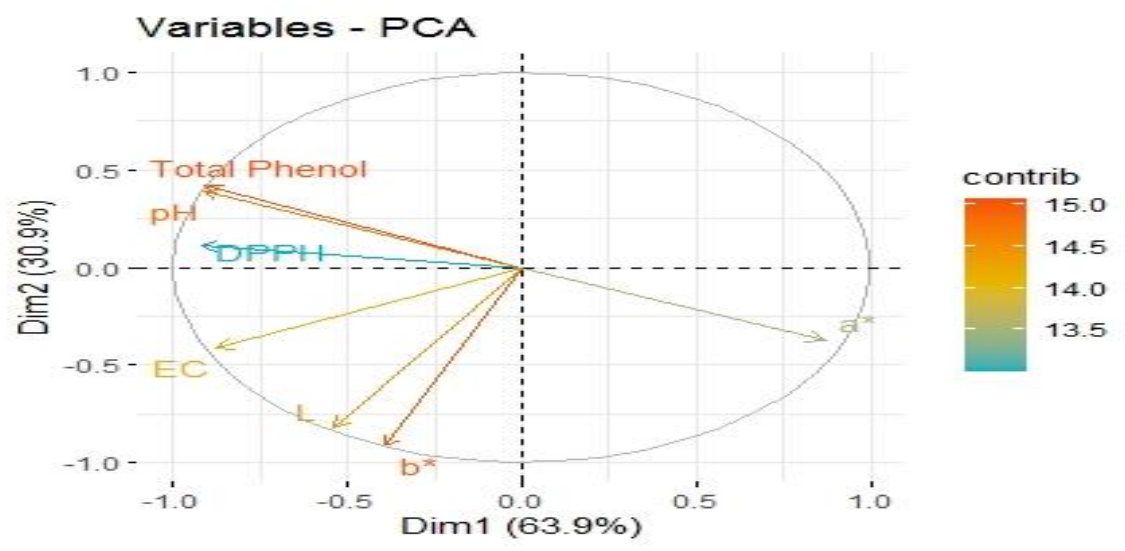

Figure 4. PCA biplot of physicochemical analyses of pollen loads 


\section{Conclusion}

Bee pollen load content varies depending on geographical origin, botanical source and beekeeping practices. According to palynological analysis, the pollen content of the samples obtained from Bitlis reflects the Eastern Anatolian flora, but the samples obtained from Muş and Tunceli do not. Muş and Tunceli samples were purchased from the market and Bitlis'samples were obtained from beekeepers. In our study, the pollen grains belonging to Cistus sp. were determined in the pollen loads from Muş and Tunceli provinces. Cistus taxon is not one of the bee plants belonging to the Eastern Anatolia region. It has been proven once again with our study that it can be determined whether the bee products sold in the market belong to that region or not by palynological analyzes. Many different test methods were used to determine the antioxidant activity of pollen samples. Each of these methods is a very important indicator for determining the antioxidant activity of the bee pollen loads. According to the results obtained in this study demonstrated that bee pollen possesses good antioxidant activity suggesting that it could be useful in prevention of diseases in which free radicals are implicated.

\section{Acknowledgement}

One of the authors of this research, İkranur Felek, is a $100 / 2000 \mathrm{PhD}$ student in the field of 'Innovative Food Processing Technologies and Food Biotechnology'. Analyses were carried out at the Bingöl University Bee and Bee Products Research Centre. The authors also thank these institutions.

\section{References}

Adaškevičiūtè, V., Kaškonienė, V., Kaškonas, P., Barčauskaitė, K., \& Maruška, A. (2019). Comparison of physicochemical properties of bee pollen with other bee products. Biomolecules, 9(12), 122. https://doi.org/10.3390/biom9120819

Almeida, J. de F., Reis, A. S. dos, Heldt, L. F. S., Pereira, D., Bianchin, M., Moura, C. de, Plata-Oviedo, M. V., Haminiuk, C. W. I., Ribeiro, I. S., Luz, C. F. P. da, \& Carpes, S. T. (2017). Lyophilized bee pollen extract: A natural antioxidant source to prevent lipid oxidation in refrigerated sausages. LWT - Food Science and Technology, 76, 299-305. https://doi.org/10.1016/j.lwt.2016.06.017

Atanassova, J., \& Lazarova, M. (2010). Pollen analysis of bee pollen loads from the region of the town of Shumen (NE Bulgaria). Comptes Rendus de L'Academie Bulgare Des Sciences, 63(3), 369-374.

Barth, O. M., Freitas, A. S., Oliveira, É. S., Silva, R. A., Maester, F. M., Andrella, R. R. S., \& Cardozo, G. M. B. Q. (2010). Evaluation of the botanical origin of commercial dry bee pollen load batches using pollen analysis: A proposal for technical standardization. Anais Da Academia Brasileira de Ciencias, 82(4), 893-902. https://doi.org/10.1590/S0001-37652010000400011

Bay, V., Topal, E., Çakıcı, N., Yıldızdal, İ., \& Tosunoglu, A. (2021). Palynological analyses, chemical and mineral substances of some honeybee polen pellets. Uludağ Arıcılık Dergisi, October. https://doi.org/10.31467/uluaricilik.996036

Bobiş, O., Mărghitaş, L. A., Dezmirean, D., Morar, O., Bonta, V., \& Chirilă, F. (2010). Quality parameters and nutritional value of different commercial bee products. Bulletin UASVM Animal Science and Biotechnologies, 67, 1-2.

Carpes, S. T., Prado, A., Moreno, I. A. M., Mourão, G. B., De Alencar, S. M., \& Masson, M. L. (2008). Avaliação do potencial antioxidante do pólen apícola produzido na região sul do Brasil. Quimica Nova, 31(7), 1660-1664. https://doi.org/10.1590/S010040422008000700011

Fatrcová-Šramková, K., Nôžková, J., Kačániová, M., Máriássyová, M., Rovná, K., \& Stričík, M. (2013). Antioxidant and antimicrobial properties of monofloral bee pollen. Journal of Environmental Science and Health - Part B Pesticides, Food Contaminants, and Agricultural Wastes, 48(2), 133-138. https://doi.org/10.1080/03601234.2013.727664

Feas, X., Vazquez-Tato, M. P., Estevinho, L., Seijas, J. A., \& Iglesias, A. (2012). Organic bee pollen: Botanical origin, nutritional value, bioactive compounds, antioxidant activity and microbiological quality. Molecules, 17(7), 8359-8377. https://doi.org/10.3390/molecules17078359

Freire, K. R. L., Lins, A. C. S., Dórea, M. C., Santos, F. A. R., Camara, C. A., \& Silva, T. M. S. (2012). Palynological origin, phenolic content, and antioxidant properties of honeybee-collected pollen from Bahia, Brazil. Molecules, 17(2), 1652-1664. https://doi.org/10.3390/molecules17021652

Genç, F., \& Dodoloğlu, A. (2002). Arıcılığın temel esasları. Atatürk Üniv. Ziraat Fak. Ders Yayınları, (166), 338.

Khalil, F. A., \& El-sheikh, N. M. (2010). The effects of dietary Egyptian propolis and bee pollen supplementation against toxicity of sodium fluoride in rats. Veterinary Medical Journal Giza, 58(2), 163-175.

Kostić, A., Milinčić, D. D., Barać, M. B., Shariati, M. A., Tešić, Ž. L., \& Pešić, M. B. (2020). The application of pollen as a functional food and feed ingredient-the present and perspectives. Biomolecules, 10(1). https://doi.org/10.3390/biom10010084

LeBlanc, B. W., Davis, O. K., Boue, S., DeLucca, A., \& Deeby, T. (2009). Antioxidant activity of Sonoran Desert bee pollen. Food Chemistry, 115(4),.1299-1305. https://doi.org/10.1016/j.foodchem.2009.01.055

Lima, W. G., Brito, J. C. M., \& da Cruz Nizer, W. S. (2021). Bee products as a source of promising therapeutic and chemoprophylaxis strategies against COVID-19 (SARS-CoV-2). Phytotherapy Research, 35(2), 743-750. https://doi.org/10.1002/ptr.6872

Modro, A. F. H., Silva, I. C., Luz, C. F. P., \& Message, D. (2009). Analysis of pollen load based on color, physicochemical composition and botanical source. Anais Da Academia Brasileira de Ciencias, 81(2), 281-285.

https://doi.org/10.1590/S000137652009000200014

Pascoal, A., Rodrigues, S., Teixeira, A., Feás, X., \& Estevinho, L. M. (2014). Biological activities of commercial bee pollens: Antimicrobial, antimutagenic, antioxidant and antiinflammatory. Food and Chemical Toxicology, 63, 233-239. https://doi.org/10.1016/j.fct.2013.11.010

Saroglu, O. (2018). Detection of some quality properties and antioxidant activity of bee products like; honey, pollen and propolis obtained from Bayburt and different regions of Turkey, Istanbul Technical Univercity, Institute of Science, Istanbul, Turkey, 1-99.

Tsao, R., \& Deng, Z. (2004). Separation procedures for naturally occurring antioxidant phytochemicals. Journal of Chromatography B: Analytical Technologies in the Biomedical and Life Sciences, 812(1-2 SPEC. ISS.), 85-99. https://doi.org/10.1016/j.jchromb.2004.09.028

Yang, K., Wu, D., Ye, X., Liu, D., Chen, J., \& Sun, P. (2013). Characterization of chemical composition of bee pollen in China. Journal of Agricultural and Food Chemistry, 61(3), 708718. https://doi.org/10.1021/jf304056b 